\title{
REDESCRIPTION OF THE FEMALE OF PODOCINUM CATENUM ISHIKAWA, 1970 (ACARI: MESOSTIGMATA: PODOCINIDAE) WITH NEW RECORDS IN WESTERN SIBERIA
}

\author{
Viacheslav A. Trach ${ }^{1,2^{*}}$, Irina I. Marchenko ${ }^{3}$ and Omid Joharchi ${ }^{4}$ \\ ${ }^{1}$ Odessa I. I. Mechnikov National University, Odessa, Ukraine \\ ${ }^{2}$ Ukrainian I. I. Mechnikov Anti-Plague Research Institute, Odessa, Ukraine \\ ${ }^{3}$ Institute of Systematics and Ecology of Animals, Novosibirsk, Russia \\ ${ }^{4}$ Institute of Environmental and Agricultural Biology (X-BIO), Tyumen State University, \\ Tyumen, Russia \\ *corresponding author; e-mail: vatrach@gmail.com
}

\begin{abstract}
A detailed redescription of a female Podocinum catenum Ishikawa, 1970 is provided with the aid of SEM microscopy. $P$. catenum is recorded for the first time from Western Siberia. Our finding is the northernmost locality for the family Podocinidae $\left(57^{\circ} 21^{\prime} \mathrm{N}\right)$. A key to the species of Podocinum occurring in Asian Russia is provided.
\end{abstract}

KEY WORDS: Mite, Parasitiformes, Gamasina, morphology, SEM microscopy.

DOI: 10.21684/0132-8077-2019-27-1-95-105

\section{INTRODUCTION}

Predatory mites of the genus Podocinum Berlese, 1882 are free-living representatives of the soil fauna. Most species of this genus are known from Asia, but some species have been reported from the North and South America, Europe, Africa, and Australia (Evans and Hyatt 1958; Athias-Henriot 1959; De Leon 1964; Bregetova 1977; Błaszak and Alberti 1985; Lindquist and $\mathrm{Wu}$ 1987; Halliday 1990; Yan et al. 2012; Santos et al. 2017). Currently, the genus Podocinum includes 31 described species (Yan et al. 2012; Santos et al. 2017).

Three species of the genus Podocinum have been reported from the Asian Russia: Podocinum aokii Ishikawa, 1970; P. catenum Ishikawa, 1970; P. sibiricum Volonikhina, 1999. All of them, with the exception of $P$. sibiricum, are known only from the Far East (Bregetova 1977; Volonikhina 1999).

During the survey of the soil mites in Western Siberia (Tyumen Region), a series of female specimens of the genus Podocinum were collected. They were identified as Podocinum catenum. This species was described from Japan, although it also occurs in the Far East of Russia (Kamchatka Peninsula, Sakhalin and Kunashir Islands, Primorsky Territory, Khabarovskii Territory) (Bregetova 1977; Volonikhina 1999).

The purpose of this paper is to redescribe and provide SEM illustrations of Podocinum catenum females.

\section{MATERIAL AND METHODS}

The mites were collected from the soil and litter using Berlese funnels, and were preserved in plastic vials filled with ethanol. Some specimens were mounted in Hoyer's medium for the purposes of light-microscopy. The morphology of mites was studied with the aid of an Axioskop 40 microscope (Carl Zeiss) and an Axio Imager A2 microscope (Carl Zeiss) with DIC and phasecontrast objectives. For SEM microscopy, alcoholpreserved mites were dried in a JFD 320 freeze dryer (JEOL), dusted with gold and scanned using a JSM-6510LV SEM microscope (JEOL).

The morphological terminology generally follows Evans and Till (1979). Dorsal and ventral setae were labelled according to the systems of Lindquist and Evans (1965). Palpal and leg chaetotaxy follows Evans (1963a, b). All pore-like structures on dorsal shield, glandular openings (solenostomes) and poroids (lyrifissures) are designated as "pores". The notation for ventral idiosomal pore-like structures, both gland pores and poroids, generally follows Athias-Henriot (1971, 1975). Lengths of shields were measured from the anterior to posterior shield margins along the midline. The length of the second cheliceral segment was measured from its base to the apex of the fixed digit. The lengths of legs were measured from the base of the coxa to the apex of the tarsus, excluding the ambulacrum. The measurements are given in micrometers $(\mu \mathrm{m})$. Podocinum catenum Ishikawa, 1970 is redescribed based on the specimens collected in Western Siberia (Tyumen Region). The main measurements of mites from Western Siberia and other regions of Russia (Northern Altai, Khabarovskii Territory, Primorskii Territory and 
Sakhalin) are given in Table 1. The studied material has been deposited in the Zoological Museum of Tyumen State University (Tyumen, Russia), in the collections of the Department of Zoology of Odessa I.I. Mechnikov National University (Odessa, Ukraine) and in the Zoological Museum of Institute of Systematics and Ecology of Animals (Novosibirsk, Russia).

\section{SYSTEMATICS}

\section{Family Podocinidae}

Genus Podocinum Berlese, 1882b

Type species: Laelaps sagax Berlese, 1882a, by original designation

Diagnosis. The diagnosis of Podocinum used here is based on that of Santos et al. (2017).

\section{PODOCINUM CATENUM ISHIKAWA, 1970}

Figs. 1-29

Podocinum catenum Ishikawa, 1970, p. 116, figs. 14-20.

Diagnosis. Dorsal shield without lateral incisions; all surface covered by small angular protuberances connected by bridges (generally) and arranged in a distinct polygonal network of pentagons-heptagons; with 19 pairs of setae (setae $j 1, j 3, j 5, j 6, z 5, s 2-s 5$, S4 smooth and blunted; setae j2, J3-J5, Z3, Z4, S5 thick, long and strongly serrated; setae $J 1, Z 1$ slightly thickened and serrated). Ventrianal shield inverted dome-shaped; its length/width ratio 0.75-0.90; setae JV5 absent. Left and right peritremes fused in front of anterior margin of dorsal shield. Central extension of epistome with two-five branches (usually bifurcate); subcapitular seta $h p 2$ inserted slightly posteriad of $h p 3$; palptarsal apotele 3-tined. Tarsi II-IV with 18 setae (33/2 1/13/23); largest sub-distal seta on tarsus I short, usually shorter than the half of the distance between its base and apex of tarsus.

Redescription of female (Figs. 1-29). Twelve specimens from Western Siberia measured.

Idiosomal dorsum (Figs. 1, 16-22). Dorsal shield ovoid, golden-brown in colour, without lateral incisions, its laterocaudal margin bent ventrally; 437497 long and 304-381 maximum wide at $Z 1$ level; surface covered by small protuberances usually connected by bridges and arranged in a distinct polygonal pentagon-heptagon network (Figs. 19, $21)$; with 19 pairs of setae $(j 1-j 3, j 5, j 6, z 5, s 2-s 5$, $J 1, J 3, J 4, J 5, Z 1, Z 3, Z 4, S 4, S 5$, setae $S 4$ and base of setae $S 5$ visible ventrally) and nine pairs of distinguishable pore-like structures (Fig. 22). Setae $j 1$, $j 3, j 5, j 6, z 5, s 2-s 5, S 4$ smooth and blunted (Fig. 21); setae $j 2, J 3-J 5, Z 3, Z 4, S 5$ thick, long and strongly serrated (Figs. 18, 20); setae $J 1, Z 1$ slightly thickened and serrated; lengths of setae: $j 1$ 9-13, j2 90-104, j3 11-15, j5 11-15, j6 11-15, z5 11-15, s2 11-14, s3 9-13, s4 11-15, s5 18-25, J1 21-27, J3 44-53, J4 82-107, J5 80-101, Z1 25-31, Z3 88-105, Z4 95-104, S4 13-20, S5 82-105.

Idiosomal venter (Figs. 2, 3, 23-26). Base of tritosternum indistinguishable; laciniae minute, smooth, 26-32 long, separated for about 95\% of their total length. Pre-sternal area without platelets. Sternal shield fused with endopodal platelets of coxae I/II and coxae II/III; 59-63 long along midline, 126-150 wide at level of endopodal projections between coxae I/II, 138-164 wide at level of endopodal projections between coxae II/III, 84-103 wide at mid-level of coxae II (narrowest part); with three pairs of setae (st 1-st3), without pores; posterior margin weakly concave; reticulated over all of surface except smooth area between setae st 1 . Setae st4 located on metasternal platelets; poroids iv3 absent. Epigynal shield triangular with rounded anterior margin; 116-139 long, with greatest width in posterior part 135-147; with number of longitudinal lines; with a pair of setae st 5 and poroids $i v 5$. Clear endopodal plates formed between coxae III and IV (Fig. 24). Gland pores gv2 located on soft cuticle behind coxae IV. Ventrianal shield roundish triangular in form, posterior margin indented medially; 147-163 long and 176-197 wide, length/width ratio $0.79-0.90$; shield ornamented with transverse lines anteriorly; anus flanked by ornamental archeslaterally; cribrum well developed; shield with four pairs of opisthogastric setae $(J V 1, J V 3, J V 4$ and $Z V 2$ ) in addition to circumanal setae and two pairs of pores (including gv3) (Fig. 25). Soft cuticle around ventrianal shield without metapodal platelets and setae. All ventral setae simple and pointed; lengths of setae: st 1 20-26, st2 20-26, st3 20-24, st4 19-21, st5 17-24, JV1 17-24, JV3 17-24, JV4 26-33, ZV2 18-26, para-anal seta 15-20, post-anal seta 13-19. Exopodal platelets laterad coxae II-IV merged into a band fused posteriorly with reduced peritrematal shield. Left and right peritremes fused in front of anterior margin of dorsal shield. Peritrematic plate fused with dorsal shield at level of setae $j 3-s 2$, extending posteriad beyond coxa IV up to level of posterior margin of epigynal shield (Figs. $19,26)$, bearing only one pore, namely $g p 3$. Spermathecal apparatus weakly sclerotized; induction pore (solenostome) apparently at posteroproximal region of coxa III; tubuli long and fusing before entering sacciform sacculus (Fig. 3). 


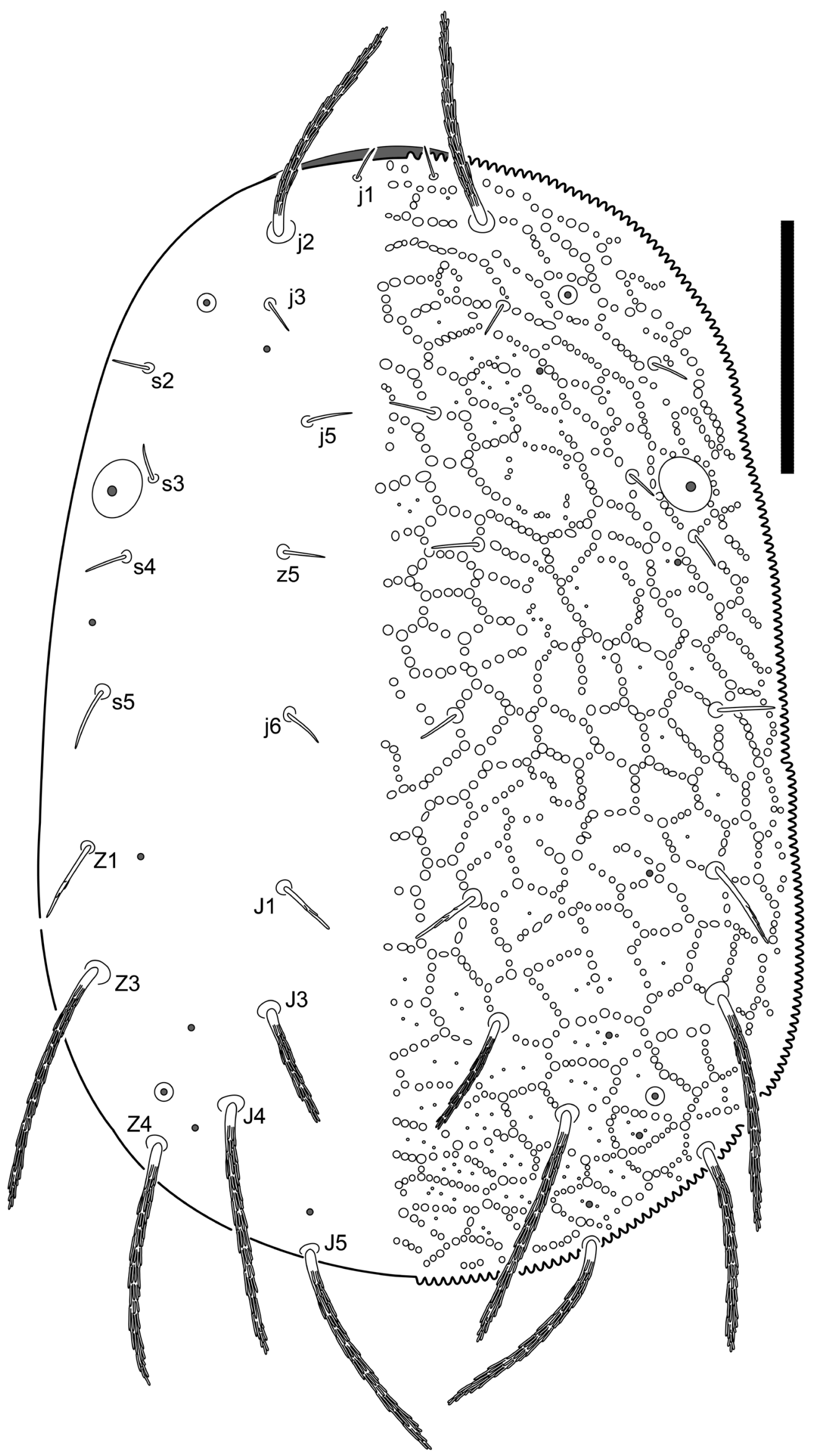

Fig. 1. Podocinum catenum Ishikawa, 1970, female: idiosoma, dorsal view. Scale bar=100 $\mu \mathrm{m}$. 


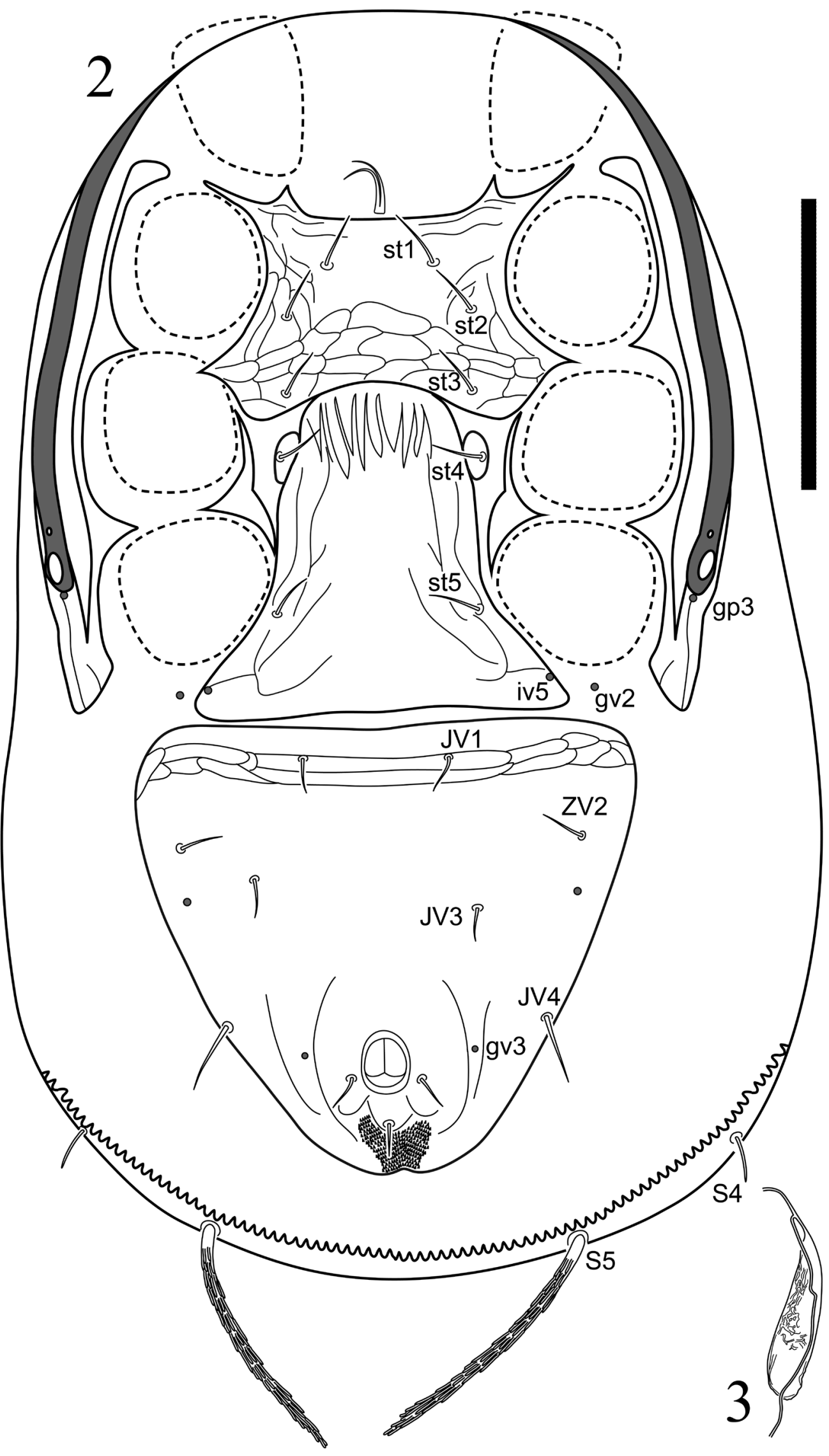

Figs. 2-3. Podocinum catenum Ishikawa, 1970, female: 2-idiosoma, ventral view; 3-spermathecal apparatus. Scale bar $=100 \mu \mathrm{m}$. 

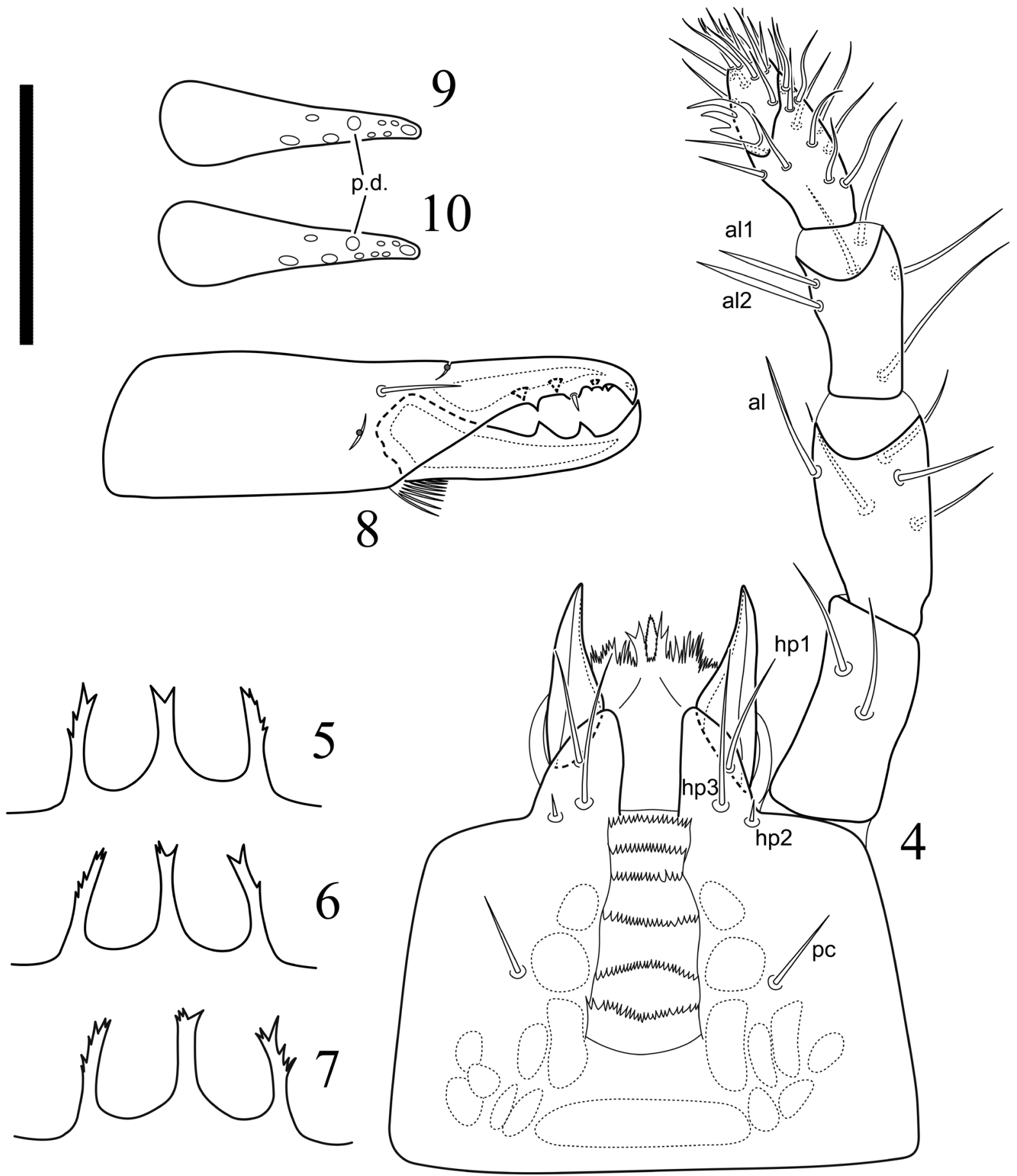

Figs. 4-10. Podocinum catenum Ishikawa, 1970, female: 4 - subcapitulum and palp; 5-7-variety of shape of epistome; 8 - chelicera, lateral view; 9-10-variety of shape of fixed digit, ventral view. Scale bar=50 $\mu \mathrm{m}$.

Gnathosoma (Figs. 4-10, 18, 27-29). Anterior region of epistome with three distally divided extensions, lateral extensions with outer margin denticulate, central extension with two-five branches (usually bifurcate) (Figs. 5-7, 29). Subcapitulum 97-108 wide, 107-119 long. Deutosternum with six rows of small denticles, all rows connected by lateral lines; anterior three rows each with 15-20 denticles, posterior three rows each with 20-25 denticles. Subcapitular setae lengths: palpcoxal seta ( $p c$ ) 17-20, hp1 19-26, hp2 5-8, hp3 25-34; seta $h p 3$ inserted slightly anteriad of hp2. Corniculi 30-37 long, 10-15 wide, horn-like. Internal malae fused and fringed, their internal 


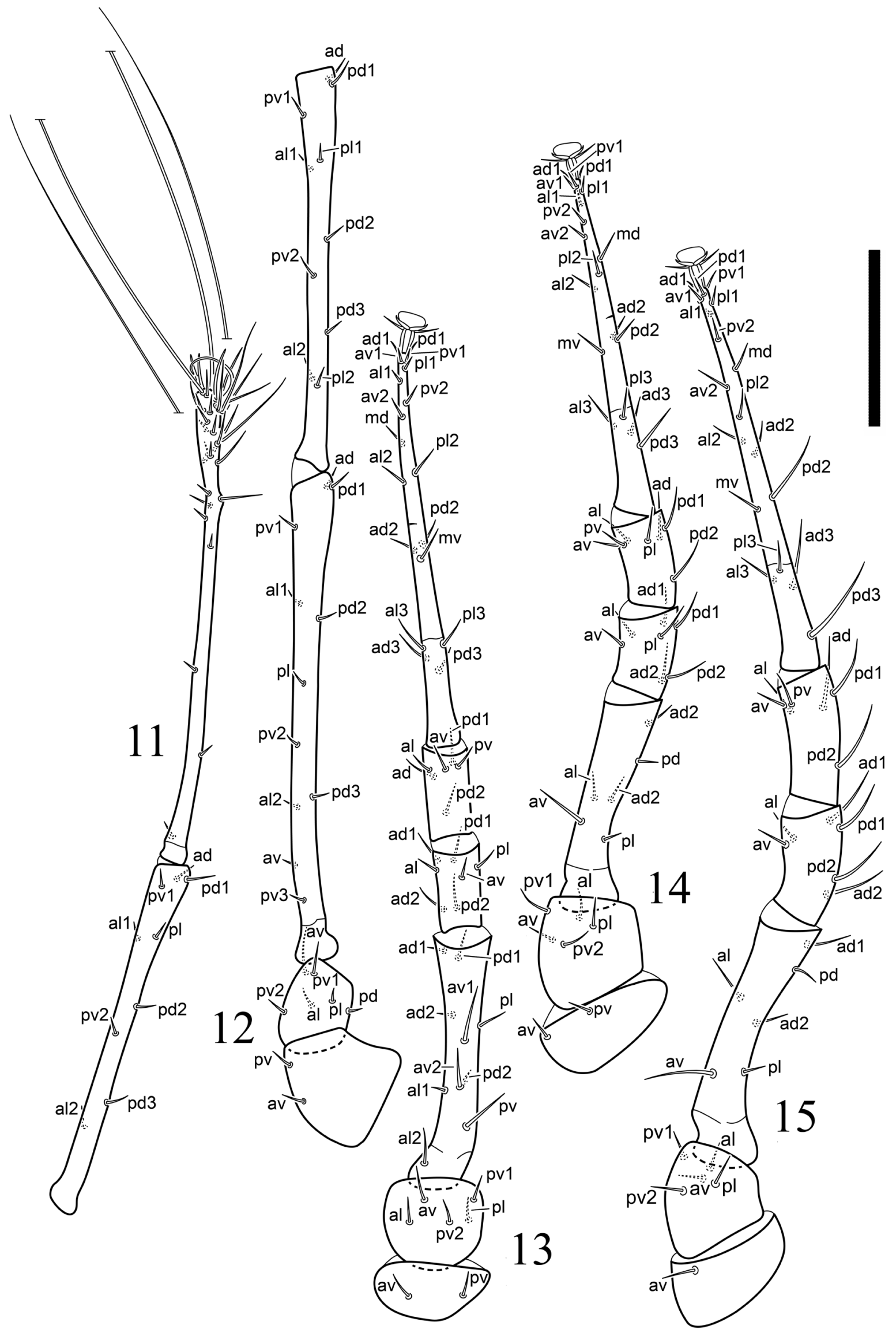

Figs. 11-15. Podocinum catenum Ishikawa, 1970, female: 11-tibia I-tarsus I; 12 — coxa I-genu I; 13-leg II; 14—leg III; 15 - leg IV, ventral view. Scale bar $=100 \mu \mathrm{m}$. 


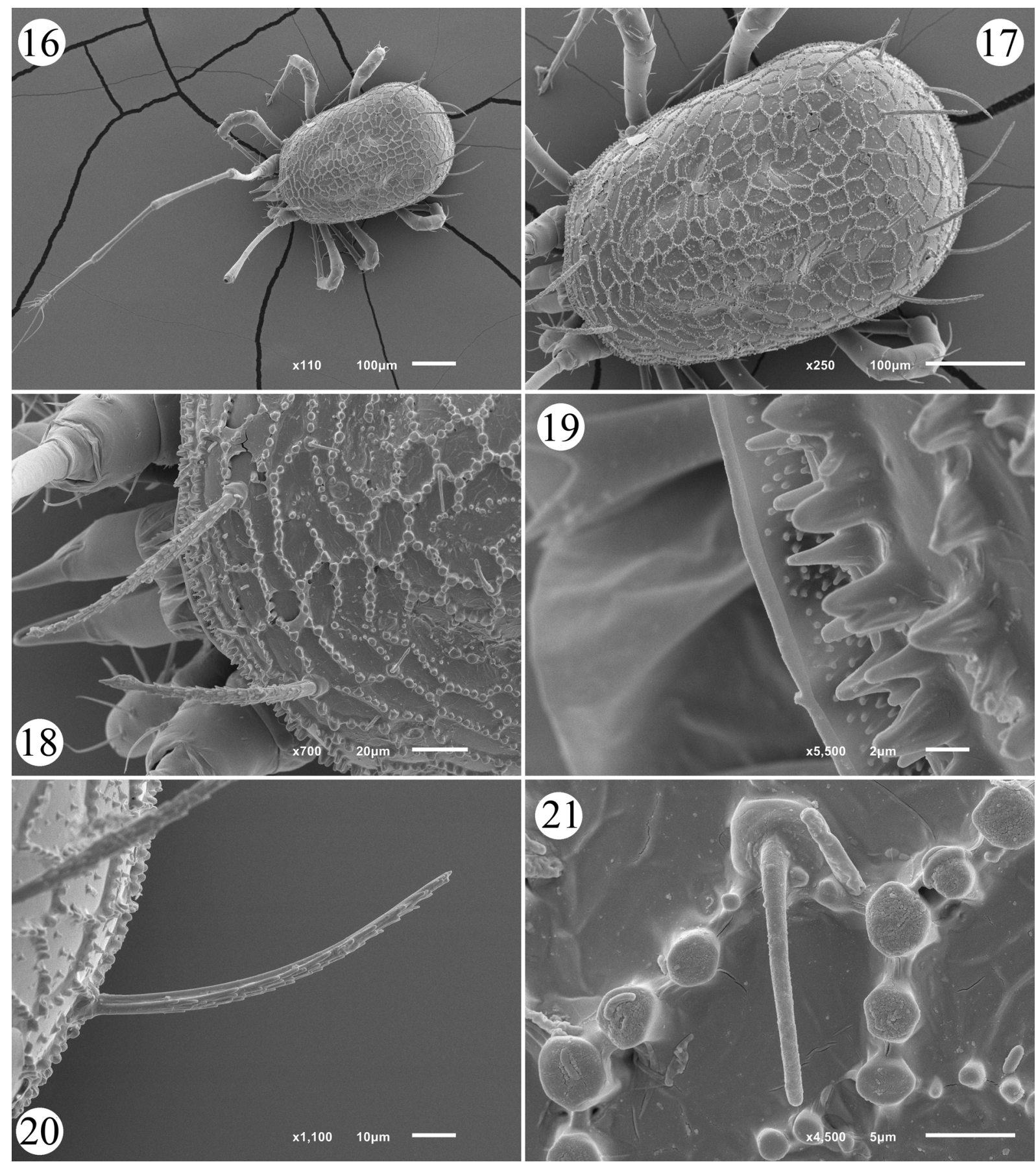

Figs. 16-21. Podocinum catenum Ishikawa, 1970, female, SEM micrographs: 16 - general view, dorsally; 17-idiosoma, dorsally; 18 - front of idiosoma, dorsal view; 19 — anterior margin of dorsal shield with fused peritremes; 20 — modified dorsal seta; 21 - simple dorsal seta and fragment of dorsal shield ornamentation.

processes reaching tip of labrum and not reaching tips of corniculi (Figs. 4, 27, 28). Palp length from trochanter base to tarsus apex 164-174; setal formula: 2-5-6-14-15; palpfemoral seta al slightly curved and spatulate, palpgenual setae all and al2 xiphoid, palptarsal apotele 3-tined (Figs. 27, 28). Second cheliceral segment length 105-109, movable and fixed digits of equal length, 48-53. Fixed cheliceral digit with three larger teeth, four (rarely five) smaller teeth and pilus dentilis on a roundish elevated base in addition to apical hook; antiaxial and dorsal lyrifissure, and chelaseta distinct; movable digit with two teeth in addition to apical hook (Figs. 8-10, 29).

Legs (Figs. 11-15). Lengths: I 1,022-1,144, II 539-558, III 493-539, IV 586-632. Leg chaetotactic formulae - leg I: coxa 2, trochanter $6\left(\begin{array}{lll}1 & 0 / 1 & 1 / 2\end{array}\right.$ 1), femur 11 (2 1/1 3/2 2), genu 10 (2 1/0 3/2 2), 

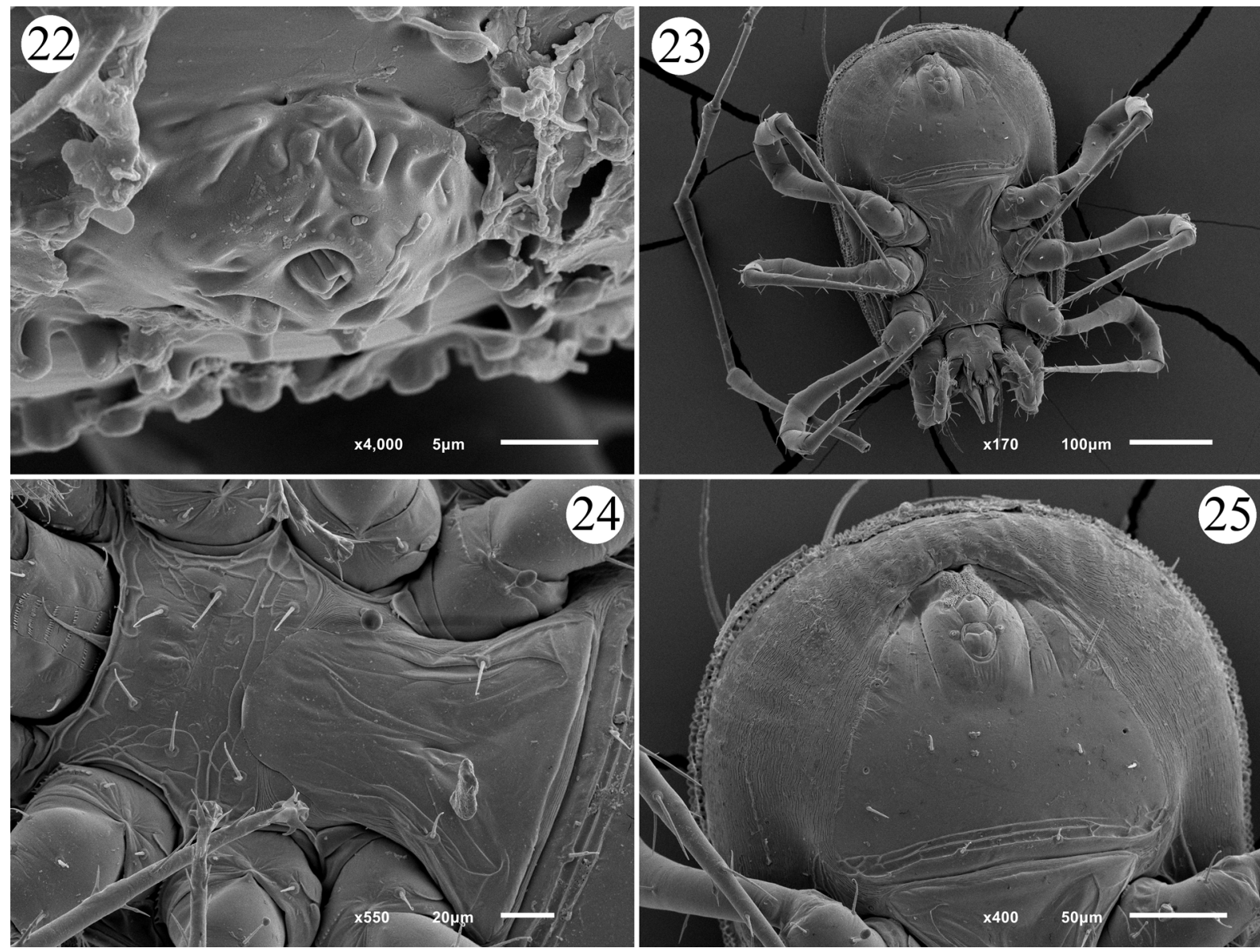

Figs. 22-25. Podocinum catenum Ishikawa, 1970, female, SEM micrographs: 22-largest dorsal pore; 23-general view, ventrally; 24-sternal-genital region; 25-ventrianal region.

tibia 9 (2 1/0 3/2 1); leg II: coxa 2, trochanter 5 (1 0/1 0/2 1), femur 10 (2 2/2 2/1 1), genu 7 (1 2/1 2/0 1), tibia 7 (1 1/1 2/1 1); leg III: coxa 2, trochanter $5(10 / 10 / 2$ 1), femur $6(12 / 11 / 01)$, genu 7 (1 2/1 2/0 1), tibia 7 (1 1/1 2/1 1); leg IV: coxa 1, trochanter $5(10 / 10 / 21)$, femur $6(12 / 11 / 01)$, genu $6(1$ 2/0 2/1 0$)$, tibia $6(11 / 12 / 10)$. Tarsi II-IV: 18 (3 $3 / 21 / 13 / 23)$. Tarsus I without ambulacrum, with a pair of very long (ca. 400 long) terminal setae, lengths of largest sub-distal setae 23-26, length from its base to apex of tarsus 59-66. Ambulacra of II-IV with claws, pulvilli rounded, paradactyli elongate and acuminate. All leg setae simple (excluding whip-like terminal setae on tarsus I).

Material examined. Five females, Russia, Tyumen Region, Nizhnetavdinsky Disctict, vicinity of Lake Kuchak, $57^{\circ} 21^{\prime} \mathrm{N}, 66^{\circ} 03^{\prime} \mathrm{E}$, from rotting wood in the linden forest, 1 August 2018, A.A. Khaustov coll.; seven females, same locality, 26 September 2018, A.A. Khaustov coll.; one female, North Altai, vicinity of Cherga village, $51^{\circ} 34^{\prime} \mathrm{N}, 85^{\circ} 33^{\prime} \mathrm{E}$, Betula sp. forest, in litter, 22 July 1994, I.I. Volonikhina coll.; five females,
Khabarovskii Territory, Range Bolschoi Khekhtsir, $48^{\circ} 03^{\prime} \mathrm{N}, 134^{\circ} 41^{\prime} \mathrm{E}$, mixed forest with Pinus koraiensis, in litter, 29 August 1991, I.I. Volonikhina coll.; five females, Khabarovskii Territory, Komsomolsk-na-Amure District, vicinity of Pivan village, $50^{\circ} 43^{\prime} \mathrm{N}, 137^{\circ} 04^{\prime} \mathrm{E}$, Quercus sp. forest, in litter, 9 August 2009, V.V. Dubatolov coll.; five females, Primorskii Territory, Ussuriiskii Natural Reserve, $43^{\circ} 40^{\prime} \mathrm{N}, 132^{\circ} 32^{\prime} \mathrm{E}$, mixed forest, in litter, 23 August 1978, V.V. Nikolskii; five females, South Sakhalin, vicinity of Nevelsk, $46^{\circ} 40^{\prime} \mathrm{N}$, $141^{\circ} 51^{\prime} \mathrm{E}$, mixed forest, in litter, 31 July 1990 , I.I. Volonikhina coll.

Remarks. This discovery of Podocinum catenum is the northernmost locality for the family Podocinidae $\left(57^{\circ} 20^{\prime} \mathrm{N}\right)$. Previously, only three species were known from the territories north of the $50^{\circ} \mathrm{N}$ latitude (all from Russia): Podocinum catenum was reported from south of Kamchatka Peninsula (exact locality not mentioned, probably ca. $50-55^{\circ} \mathrm{N}$ ); Podocinum pacificum Berlese, 1895 was found in the Saratov Region (vicinity of Saratov, ca. $51^{\circ} 30^{\prime} \mathrm{N}$ ); and Podocinum sibiricum was 

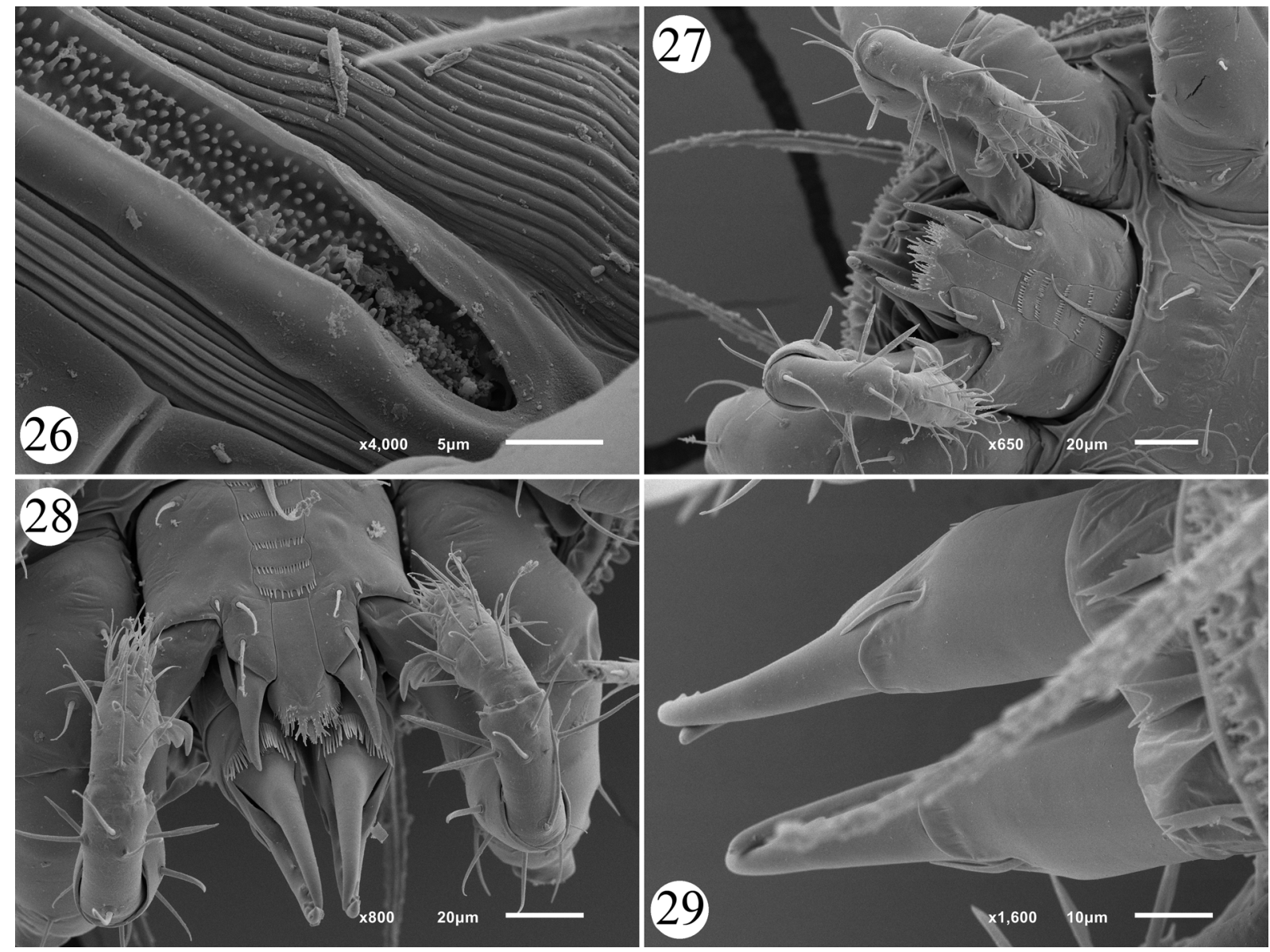

Figs. 26-29. Podocinum catenum Ishikawa, 1970, female, SEM micrographs: 26-peritreme; 27-28-gnathosoma, ventral view; 29 - chelicera, ventral view.

recorded in Northeast Altai $\left(52^{\circ} 34^{\prime} \mathrm{N}\right)$ (Bregetova 1977; Marchenko 2010).

All studied individuals of Podocinum catenum were adult females, no males or immatures were found, although males of this species are described. Males of this genus are apparently rare. Of the 31 described species of Podocinum, males are known just in seven species so far (Podocinum aciculatum Evans and Hyatt, 1958; P. aokii; P. catenum; P. jianfenglingense Liang, 1993; $P$. pintungense Ho, Ma and Wang, 2009; P. sagax (Berlese, 1882); P. tsushimanum Ishikawa, 1970).

\section{Key to the species of Podocinum Berlese of Asian Russia (females)}

1. Shape of setae $J 1$ and $Z 1$ similar to shape of setae $j 2, J 3-J 5, Z 3, Z 4, S 5$; setae $J 1$ and $Z 1$ long enough to reach base of posterior seta next in series. Ratio (length/width) of ventrianal shield ca. 0.6. Largest sub-distal seta on tarsus I usually longer than the half of the distance between its base and apex of tarsus ...... P. sibiricum Volonikhina, 1999
- Setae $J 1$ and $Z 1$ slightly thickened and serrated (setae $j 2, J 3-J 5, Z 3, Z 4, S 5$ robust and strongly serrated); setae $J 1$ and $Z 1$ shorter, never reach base posterior seta next in series. Ratio (length/width) of ventrianal shield ca. 0.8. Largest sub-distal seta on tarsus I usually shorter than the half of the distance between its base and apex of tarsus ........... 2 2. Setae $j 3, j 5, j 6, z 5, s 3-s 5, S 4$ smooth. Protuberances on dorsal shield round or oval and normally connected by bridges....P. catenum Ishikawa, 1970 - All or most of setae $j 3, j 5, j 6, z 5, s 3-s 5, S 4$ serrated. Protuberances on dorsal shield angular and not connected by bridges... P. aokii Ishikawa, 1970

\section{ACKNOWLEDGEMENTS}

The authors thank Dr. Alexander A. Khaustov (Tyumen State University, Tyumen, Russia) for providing material for study, as well as for his valuable comments on the manuscript; Andrei N. Bobylev (Tyumen State University, Tyumen, Russia) for preparing the SEM photos; Vladimir V. Dubatolov (Institute of Systematics and Ecology of 
Animals, Novosibirsk, Russia) for collecting material in the Khabarovskii Territory; Olga L. Makarova (A.N. Severtsov Institute of Ecology and Evolution, Moscow, Russia) and the anonymous reviewer for their suggestions for the improvement of this paper. The study of Irina I. Marchenko was supported by the Russian Federal Fundamental Scientific Research Program №AAAA-A16-116121.

\section{REFERENCES}

Athias-Henriot, C. 1959. Contributions aus genres Podocinum Berlese and Pleuronectocelaeno Vitzthum en Algerie and remarques sur les genres Aceosejus Sellnick and Seiodes Berlese (Mesostigmata). Acarologia, 1: 23-38.

Athias-Henriot, C. 1971. La divergence néotaxique des Gamasides (Arachnides). Bulletin Scientifique de Bourgogne, 28: 93-106.

Athias-Henriot, C. 1975. Nouvelles notes sur les Amblyseiini II. Le relevé organotaxique de la face dorsale adulte (Gamasides Protoadenique, Phytoseiidae). Acarologia, 17: 20-29.

Berlese, A. 1882a. Note Acarologiche. Atti Istituto Veneto di Scienze, Lettere ed Arti, Series 5, 8: 619-647.

Berlese, A. 1882b. Acari, Myriopoda et Scorpiones hucusque in Italia reperta. Fasc. 1, N 1. Padova.

Błaszak, C. and Alberti, G. 1985. Podocinidae Berlese, 1913 - eine neue Milbenfamilie (Acari, Mesostigmata) in der Bundesrepublik Deutschland. Zoologischer Anzeiger, Jena, 215, 3/4: 168-176.

Bregetova, N.G. 1977. Fam. Podocinidae Berlese, 1913 (sensu Evans, Hyatt, 1958). In: M.S. Ghilyarov and N.G. Bregetova (Eds.). Key to the Soil-Inhabiting Mites. Mesostigmata. Nauka, Leningrad, pp. 254-256. [In Russian]

De Leon, D. 1964. Two new Podocinum from the United States with distribution notes on three described species (Acarina: Podocinidae). Florida Entomologist, 47: 39-44. https://doi.org/10.2307/ 3493762

Evans, G.O. 1963a. Observations on the chaetotaxy of the legs in the free-living Gamasina (Acari: Mesostigmata). Bulletin of the British Museum (Natural History), Zoology, 10: 277-303. https://doi. org/10.5962/bhl.part.20528

Evans, G.O. 1963b. Some observations on the chaetotaxy of the pedipalps in the Mesostigmata (Acari). Annals and Magazine of Natural History, Series 13, 6: 513527. http://dx.doi.org/10.1080/00222936308651393

Evans, G.O. and Hyatt, K.H. 1957. The genera Podocinum Berl. and Podocinella gen. nov. (Acarina: Mesostigmata). Annals and Magazine of Natural
History, 10: 913-932. https://doi.org/10.1080/ 00222935708656095

Evans, G.O. and Till, W.M. 1979. Mesostigmatic mites of Britain and Ireland (Chelicerata: Acari-Parasitiformes). An introduction to their external morphology and classification. Transactions of the Zoological Society of London, 35: 139-270. http:// dx.doi.org/10.1111/j.1096-3642.1979.tb00059.x

Halliday, R.B. 1990. The occurrence in Australia of Podocinidae (Acarina: Mesostigmata), with description of two new species. Journal of the Australian Entomological Society, 29: 277-280. https://doi. org/10.1111/j.1440-6055.1990.tb00363.x

Ho, C.C., Ma, L.M. and Wang, S.C. 2009. A new species and two new records of Podocinum (Berlese, 1882) from Taiwan (Podocinidae: Mesostigmata). Formosan Entomologist, 29: 83-94.

Ishikawa, K. 1970. Studies on the mesostigmatid mites in Japan III. Family Podocinidae Berlese. Annotationes Zoologicae Japonenses, 3: 112-122.

Liang, L.R. 1993. Studies on the genus Podocinum Berlese in China (Acari: Podocinidae). Acta Zootaxonomica Sinica, 18: 54-62. [In Chinese]

Lindquist, E.E. and Evans G.O. 1965. Taxonomic concepts in the Ascidae, with a modified setal nomenclature for the idiosoma of the Gamasina (Acarina: Mesostigmata). Memoirs of the Entomological Society of Canada, 47: 1-65. http://dx.doi. org/10.4039/entm $9747 \mathrm{fv}$

Lindquist, E.E. and Wu, K.W. 1987. First record of the mite family Podocinidae (Acari: Mesostigmata) in Canada, with notes on other records in North America. The Canadian Entomologist, 119: 779-781.

Marchenko, I.I. 2010. Soil-inhabiting gamasid mites (Acari, Mesostigmata) of North-East Altai: transformation of taxonomic, geographical and population structure of communities along an altitudinal gradient. Evraziatskii Entomologicheskii Zhurnal, 9 (4): 741-756. [In Russian]

Santos, J.C., Martins, J.P.I., Britto, E.P.J. and de Moraes, G.J. 2017. A new species of Podocinum (Acari: Podocinidae) from Brazil, and supplementary descriptions of three species of this genus. Zootaxa, 3194: 35-48. https://doi.org/10.11646/ zootaxa.4290.3.2

Volonikhina, I.I. 1999. Mesostigmatic mites of the family Podocinidae Berlese (Acari, Gamasina) from Siberia and the Far East of Russia. Acarina, 7 (1): 61-65.

Yan, Y., Jin, D.C., Wu, D., Guo, J.J. and Guo, X.G. 2012. A revised checklist and key to the genus Podocinum Berlese (Acari: Podocinidae) with description of a new species from Tibet, southwest China. Zootaxa, 4290 (3): 444-458. 
Table 1

Measurements of Podocinum catenum Ishikawa, 1970 females from different regions of Asian Russia

\begin{tabular}{|c|c|c|c|c|c|c|c|c|c|c|c|}
\hline \multirow[t]{3}{*}{ Character } & \multirow{2}{*}{\multicolumn{2}{|c|}{$\begin{array}{l}\text { Tyumen } \\
\text { Region }\end{array}$}} & \multirow{3}{*}{\begin{tabular}{|l|} 
North \\
Altai
\end{tabular}} & \multirow{2}{*}{\multicolumn{2}{|c|}{\begin{tabular}{|l} 
Khabarovskii \\
Territory \\
(Range \\
Bolschoi \\
Khekhtsir) \\
n=5 \\
\end{tabular}}} & \multirow{2}{*}{\multicolumn{2}{|c|}{$\begin{array}{l}\text { Khabarovskii } \\
\text { Territory } \\
\text { (Komsomolsk- } \\
\text { na-Amure } \\
\text { District) } \\
\text { n=5 }\end{array}$}} & \multicolumn{2}{|c|}{$\begin{array}{l}\text { Primorskii } \\
\text { Territory }\end{array}$} & \multicolumn{2}{|c|}{$\begin{array}{l}\text { South } \\
\text { Sakhalin }\end{array}$} \\
\hline & & & & & & & & $n=5$ & & $n=5$ & \\
\hline & $\min$ & $\max$ & & $\min$ & $\max$ & $\min$ & $\max$ & $\min$ & $\max$ & $\min$ & $\max$ \\
\hline length of dorsal shield & 437 & 497 & 475 & 420 & 460 & 435 & 445 & 440 & 475 & 455 & 465 \\
\hline width of dorsal shield & 304 & 381 & 350 & 300 & 327 & 310 & 320 & 320 & 325 & 315 & 330 \\
\hline seta $j 1$ & 9 & 13 & 10 & 9 & 10 & 9 & 10 & 9 & 10 & 9 & 10 \\
\hline seta $j 2$ & 90 & 104 & 95 & 100 & 100 & 95 & 100 & 90 & 93 & 88 & 95 \\
\hline seta $j 3$ & 11 & 15 & 13 & 12 & 15 & 12 & 15 & 12 & 13 & 12 & 15 \\
\hline seta $j 5$ & 11 & 15 & 13 & 12 & 15 & 12 & 15 & 12 & 15 & 12 & 15 \\
\hline seta $j 6$ & 11 & 15 & 15 & 12 & 15 & 12 & 15 & 12 & 15 & 15 & 17 \\
\hline seta $z 5$ & 11 & 15 & 15 & 12 & 15 & 12 & 15 & 12 & 15 & 12 & 15 \\
\hline seta $s 2$ & 11 & 14 & 10 & 10 & 12 & 12 & 15 & 12 & 15 & 10 & 12 \\
\hline seta $s 3$ & 9 & 13 & 10 & 10 & 12 & 12 & 15 & 12 & 15 & 10 & 12 \\
\hline seta $s 4$ & 11 & 15 & 10 & 10 & 12 & 12 & 15 & 12 & 15 & 10 & 12 \\
\hline seta $s 5$ & 18 & 25 & 13 & 10 & 12 & 20 & 22 & 17 & 18 & 12 & 17 \\
\hline seta $J 1$ & 21 & 27 & 27 & 20 & 25 & 20 & 25 & 20 & 25 & 20 & 25 \\
\hline seta $J 3$ & 44 & 53 & 50 & 37 & 50 & 40 & 45 & 40 & 48 & 37 & 43 \\
\hline seta $J 4$ & 82 & 107 & 87 & 87 & 93 & 87 & 90 & 87 & 93 & 55 & 65 \\
\hline seta $J 5$ & 80 & 101 & 87 & 75 & 87 & 87 & 90 & 80 & 82 & 55 & 65 \\
\hline seta $Z 1$ & 25 & 31 & 30 & 25 & 30 & 30 & 35 & 27 & 35 & 17 & 23 \\
\hline seta $Z 3$ & 88 & 105 & 93 & 85 & 98 & 90 & 95 & 75 & 88 & 55 & 65 \\
\hline seta $Z 4$ & 95 & 104 & 95 & 88 & 100 & 87 & 90 & 80 & 88 & 65 & 80 \\
\hline seta $S 4$ & 13 & 20 & 17 & 18 & 25 & 20 & 25 & 20 & 25 & 15 & 20 \\
\hline seta $S 5$ & 82 & 105 & 90 & 75 & 88 & 95 & 100 & 75 & 83 & 65 & 75 \\
\hline width of epigynal shield & 135 & 147 & 137 & 137 & 143 & 133 & 143 & 135 & 143 & 125 & 137 \\
\hline length of ventrianal shield & 147 & 163 & 175 & 143 & 157 & 150 & 157 & 145 & 155 & 145 & 165 \\
\hline width of ventrianal shield & 176 & 197 & 200 & 177 & 192 & 187 & 200 & 180 & 193 & 177 & 190 \\
\hline $\begin{array}{l}\text { ratio (length / width) of } \\
\text { ventrianal shield }\end{array}$ & 0.79 & 0.90 & 0.88 & 0.75 & 0.84 & 0.75 & 0.80 & 0.76 & 0.83 & 0.75 & 0.86 \\
\hline seta $J V 1$ & 17 & 24 & 17 & 13 & 17 & 15 & 17 & 17 & 18 & 17 & 20 \\
\hline seta $J V 3$ & 17 & 24 & 20 & 13 & 17 & 17 & 20 & 17 & 20 & 17 & 20 \\
\hline seta $J V 4$ & 26 & 33 & 33 & 30 & 33 & 35 & 37 & 33 & 40 & 27 & 30 \\
\hline seta $Z V 2$ & 18 & 26 & 23 & 13 & 17 & 17 & 20 & 18 & 23 & 17 & 20 \\
\hline para-anal seta & 15 & 20 & 20 & 13 & 17 & 15 & 17 & 17 & 20 & 17 & 20 \\
\hline post-anal seta & 13 & 19 & 17 & 13 & 17 & 13 & 15 & 15 & 17 & 15 & 17 \\
\hline length of leg I & 1,022 & 1,144 & 1,115 & 1,095 & 1,130 & 1,087 & 1,100 & 1,100 & 1,150 & 1,000 & 1,075 \\
\hline $\begin{array}{l}\text { length of largest sub-distal } \\
\text { seta on tarsus I }\end{array}$ & 23 & 26 & 25 & 20 & 23 & 20 & 25 & 15 & 25 & 25 & 35 \\
\hline $\begin{array}{l}\text { length from base of } \\
\text { largestsub-distal seta to } \\
\text { apex of tarsus I }\end{array}$ & 59 & 66 & 63 & 58 & 63 & 58 & 63 & 58 & 65 & 58 & 63 \\
\hline
\end{tabular}

